\title{
Assimilation of inorganic nitrogen by seep mytilid Ia, an undescribed deep-sea mussel containing methanotrophic endosymbionts: fate of assimilated nitrogen and the relation between methane and nitrogen assimilation
}

\author{
Raymond W. Lee, James J. Childress* \\ Department of Biological Sciences and the Marine Science Institute, University of California, Santa Barbara, \\ California 93106, USA
}

\begin{abstract}
Undescribed deep-sea mussels containing methanotrophic endosymbionts (seep mytilid Ia) are found at high densities around hydrocarbon seeps of the Gulf of Mexico where methane, nitrate and ammonium are present at high concentrations. In this study we investigated assimilation of ammonium, nitrate, glycine and methane using ${ }^{15} \mathrm{~N}$ - and ${ }^{13} \mathrm{C}$-labelled tracers to determine sites of assimilation, rates of assimilation, and the chemical form in which assimilated $\mathrm{C}$ and $\mathrm{N}$ appears. We then investigated the interaction between inorganic nitrogen assimilation and methane assimilation to assess whether they are directly dependent on each other. ${ }^{15} \mathrm{NO}_{3}{ }^{-},{ }^{15} \mathrm{NH}_{3}$ and ${ }^{13} \mathrm{CH}_{4}$ were assimilated primarily into the gills where the bacteria are located, with negligible incorporation into symbiont-free tissue In contrast ${ }_{1}^{13} \mathrm{C}^{15} \mathrm{~N}$-glycine was assimilated equally into gill and symbiont-free tissue. These results indicate that inorganic $\mathrm{N}$ is assimilated in the gill tissue. The bulk of ${ }^{13} \mathrm{C}$ and ${ }^{15} \mathrm{~N}$ label from methane and ammonium incubations was in the $80 \% \mathrm{EtOH}$ soluble fraction, suggesting that the primary assimilation product was low-molecular-weight metabolites. Some ${ }^{13} \mathrm{C}$ was incorporated into carbon storage products. Mussels that assimilated excess ${ }^{13} \mathrm{CH}_{4}$ converted $35 \%$ of ${ }^{13} \mathrm{CH}_{4}$ into an EtOH insoluble form. Negligible ${ }^{15} \mathrm{~N}$ label was observed in this fraction. Inorganic $\mathrm{N}$ assimilation and methane assimilation were not tightly coupled. N assimilation was not affected by absence of methane or inhibition of methanotrophy. Methane assimilation was not stimulated by increased $\mathrm{N}$ assimilation. Seep mytilids were capable of luxury consumption of inorganic $\mathrm{N}$, i.e. $\mathrm{C} / \mathrm{N}$ assimilation ratios below the average $\mathrm{C} / \mathrm{N}$ ratio of mussel tissues (4.2). We believe that luxury consumption is supported by $\mathrm{C}$ reserves resulting in part from methanotrophy. From relations between $\mathrm{CH}_{4}$ and $\mathrm{N}$ source concentration and assimilation rate, we estimated the environmental conditions that result in balanced $\mathrm{C} / \mathrm{N}$ assimilation. From this analysis we predict that at environmentally realistic methane and inorganic $\mathrm{N}$ concentrations seep mytilids assimilate excess $\mathrm{CH}_{4}$.
\end{abstract}

KEY WORDS: Seep mytilid la · Methanotrophy · Chemoautotrophy - Nitrogen assimilation - Ammonium $\cdot$ Nitrate $\cdot$ Methane $\cdot$ Hydrocarbon seep

\section{INTRODUCTION}

Deep-sea mussels (seep mytilid Ia) containing methanotrophic endosymbionts are abundant and conspicuous members of chemosynthetic communities

\footnotetext{
-Addressee for correspondence
}

clustered around hydrocarbon seeps on the continental slope of the northern Gulf of Mexico (MacDonald et al. 1989, 1990a, b). At these sites, biomass is high relative to elsewhere in the deep-sea. Methane, which is abundant in the seep effluent, is an important source of energy and carbon. Inorganic sources of nitrogen are rich compared with elsewhere in the marine environment. However, the degree to which 
ammonium ( $\sum \mathrm{NH}_{3}$, the sum of $\mathrm{NH}_{4}{ }^{+}$and $\mathrm{NH}_{3}$ unless otherwise specified) from seep effluent and nitrate from bottom water contribute to methanotrophic production of organic material at hydrocarbon seeps is not known.

The ability of the bacterial symbionts that reside within the seep mytilid gills to oxidize methane as a source of energy and reduced carbon is now well documented (Childress et al. 1986, Brooks et al. 1987, Fisher et al. 1987, Fisher \& Childress 1992, Kochevar et al. 1992). Although these mussels can also filterfeed (Page et al. 1990), high rates of net C influx (Kochevar et al. 1992), shell growth in the presence of methane as sole carbon source (Cary et al. 1988), and highly depleted $\delta^{13} \mathrm{C}$ values similar to methane in the environment (Childress et al. 1986, Kennicutt et al. 1992) indicate that methane is the primary source of $C$ to the symbiotic association. Uptake of inorganic nitrogen is essential for growth based on methanotrophy, and has recently been demonstrated (Lee et al. 1992, Lee \& Childress 1994). The stable nitrogen isotope composition of these mussels is extremely variable and can be anomalously depleted in ${ }^{15} \mathrm{~N}\left(\delta^{15} \mathrm{~N}=\right.$ -12.9 to $+2.0 \%$; Brooks et al. 1987), indicating that a variety of $\mathrm{N}$ sources may be utilized and that novel mechanisms of acquisition may be involved. Although it is clear that the presence of methane is an important determinant of mussel abundance and condition in nature, it is less clear what role, if any, is played by the availability of inorganic nitrogen. The environment inhabited by these mussels is extremely $\mathrm{N}$-rich compared with areas inhabited by marine photoautotrophs and other marine symbioses. Nitrate in water surrounding mussels ranges from 9.4 to $41.0 \mu \mathrm{M}$. Ammonium in hypersaline seep effluent and sediment porewater can be in the $\mathrm{mM}$ range, but is 1.6 to $13 \mu \mathrm{M}$ in water overlying mussels that is not mixed with sediment during sampling (Lee \& Childress 1994)

Uptake and assimilation of inorganic nitrogen is regarded as an important capability of symbiotic associations. In associations between algae and invertebrates, nitrate uptake is not common whereas ammonium uptake, assimilation, and recycling are ubiquitous (Wilkerson \& Trench 1986). The prevailing depletion-diffusion model for uptake involves no participation by the host (D'Elia \& Cook 1988). Nutrients from the environment are believed to enter by diffusion, which is facilitated by low nutrient concentrations in the host tissues maintained by active symbiont uptake. However, it should be noted that host tissues contain ammonium assimilation enzymes, glutamate dehydrogenase $(\mathrm{GDH} ;$ Male \& Storey 1983, Catmull et al. 1987, Rees 1987, Rahav et al. 1989) and glutamine synthetase (GS; Rees 1987). Host assimilation of ammonium, which has been demonstrated in the hydra-Chlorella symbiosis (Rees 1987), is inconsistent with a depletion-diffusion mechanism. In an earlier study, in which we demonstrated that symbiotic mussels take up ammonium (Lee et al. 1992), our results were inconclusive with regard to whether symbiont assimilation drives ammonium uptake. Uptake was not observed in functionally aposymbiotic mussels, but the kinetics of uptake by symbiotic mussels were somewhat non-linear, which is suggestive of mechanisms other than simple diffusion into the host tissue. A gradient favoring passive influx of $\mathrm{NH}_{4}{ }^{+}$or $\mathrm{NH}_{3}$ was not. observed, and hemolymph ammonium concentrations were indistinguishable between aposymbiotic and symbiotic mussels.

The finding that symbiotic associations of invertebrates and algae do not take up ammonium following proionged exposure to darkness (Muscatine \& D'Elia 1978, Wilkerson \& Muscatine 1984, Wilkerson \& Trench 1986, Szmant et al. 1990) or when they are aposymbiotic (Muscatine et al. 1979, Wilkerson \& Muscatine 1984) is regarded as strong evidence for symbiont-mediated assimilation. These results are also consistent with assimilation of ammonium by the host where assimilation is dependent on reduced carbon skeletons as well as ATP and/or NAD(P)H resulting from symbiont activity. Stimulation of ammonium assimilation by photosynthesis does not occur in most intact associations or freshly isolated symbionts (Rees 1987). These findings indicate that in these associations, assimilation of ammonium is not directly dependent on reduced carbon produced from photosynthesis and may instead be supported by carbon reserves. Such reserves may be present in either host or symbiont tissues. Regardless of which partner assimilates ammonium, the ability to rely on carbon reserves rather than environmental methane may enable mussels to exhibit 'luxury consumption', i.e. $\mathrm{N}$ consumption in excess of requirements due to methane assimilation.

${ }^{15} \mathrm{~N}$-labelled tracers have proven useful in investigating $N$ assimilation by marine symbioses (Summons \& Osmond 1981, Summons et al. 1986, Wilkerson \& Kremer 1992, Lee \& Childress 1994) although there have been few such studies. In the present study we investigated assimilation of ammonium, nitrate, glycine, and methane using ${ }^{15} \mathrm{~N}$ - and ${ }^{13} \mathrm{C}$-labelled tracers to determine sites of assimilation, rates of assimilation, and the form in which assimilated $\mathrm{C}$ and $\mathrm{N}$ appears. We also investigated the interaction between inorganic nitrogen assimilation and methanotrophic carbon assimilation to assess whether they are directly dependent. From our physiological measurements and results of Kochevar et al. (1992), we also determined the conditions that result in $\mathrm{C} / \mathrm{N}$ assimilation ratios that equal 
the $\mathrm{C} / \mathrm{N}$ ratio of mussel tissues, to assess whether $\mathrm{C} / \mathrm{N}$ balance occurs in situ.

\section{MATERIALS AND METHODS}

Mussel collection and maintenance. Mussels were collected from depths of $>500 \mathrm{~m}$ on the Louisiana Slope of the Gulf of Mexico in August 1991, August and September 1992, and June and July 1993 using the Johnson Sea Link I and II submarines and were maintained in the laboratory as described previously by Lee et al. (1992). Mussels from 1991 were from Bush Hill $\left(27^{\circ} 47^{\prime} \mathrm{N}, 91^{\circ} 30^{\prime} 24^{\prime \prime} \mathrm{W}\right)$. Mussels from 1992 were a mixture from Bush Hill and Brine Pool $\left(27^{\circ} 43^{\prime} 24^{\prime \prime} \mathrm{N}\right.$, $\left.91^{\circ} 16^{\prime} 30^{\prime \prime} \mathrm{W}\right)$ collections. 1993 mussels came from either Bush Hill, the Brine Pool, or GC-272 $\left(27^{\circ} 40^{\prime} \mathrm{N}\right.$, $91^{\circ} 30^{\prime} \mathrm{W}$ ).

Whole mussel assimilation experiments. Freshly collected mussels were incubated at 5 to $7^{\circ} \mathrm{C}$ in the presence of ${ }^{15} \mathrm{NH}_{3},{ }^{15} \mathrm{NO}_{3}{ }^{-}$, or ${ }^{15} \mathrm{~N}^{13} \mathrm{C}$-glycine with or without ${ }^{13} \mathrm{CH}_{4}$ present. The concentrations of ammonium and nitrate in the incubations were determined to within $\pm 0.2 \mu \mathrm{M}$ (limit of detection $\sim 0.5 \mu \mathrm{M}$ ) by flowinjection analysis (FIA; Johnson \& Petty 1983, Willason \& Johnson 1986). Methane, $\mathrm{N}_{2}$ and oxygen were analyzed by gas chromatography (GC; Childress et al. 1984). Concentrations of $\mathrm{N}$ substrates and ${ }^{13} \mathrm{CH}_{4}$ were maintained by additions of concentrated stock solutions every few hours as needed. ${ }^{13} \mathrm{CH}_{4}$ stock solutions $(\sim 800$ to $900 \mu \mathrm{M})$ were made by equilibrating ${ }^{13} \mathrm{CH}_{4}$ gas (5 to $10 \mathrm{ml}, 98.8 \%{ }^{13} \mathrm{C}_{\text {i }}$ Isotec) with seawater in $60 \mathrm{ml}$ plastic syringes overnight on a shaker table at $5^{\circ} \mathrm{C}$. At the end of each incubation, mussels were dissected into gill (symbiont-containing) and mantle (symbiont-free) tissues and blotted on a paper towel. In some experiments, subsamples were frozen at $-80^{\circ} \mathrm{C}$ for later fractionation.

Excised gill incubations. Gills with a small portion of mantle tissue left attached were placed in petri dishes containing $0.2 \mu \mathrm{m}$-filtered seawater (FSW) at $5^{\circ} \mathrm{C}$ then were subdivided by cutting parallel to the filaments. These gill pieces were then placed in syringes or plastic bottles (250 to $1000 \mathrm{ml}$ ) containing ${ }^{15} \mathrm{~N}$ and ${ }^{13} \mathrm{C}$ substrates. Air bubbles were removed and the syringes or bottles placed on a shaker table at $5^{\circ} \mathrm{C}$. At the end of the incubations, mantle tissue was removed and the remainder blotted then dried at $60^{\circ} \mathrm{C}$.

Tissue fractionation. Untreated samples contained ${ }^{15} \mathrm{~N}$ and ${ }^{13} \mathrm{C}$ in both inorganic and organic form. To remove ammonium and $\mathrm{CO}_{2}$, dry untreated samples were first ground to a fine powder. $2 \mathrm{~N} \mathrm{NaOH}$ was added and the samples were then kept at 20 to $25^{\circ} \mathrm{C}$. After 24 to $48 \mathrm{~h}, 2 \mathrm{~N} \mathrm{HCl}$ was added and the samples were then re-dried. These samples, from which ammo- nium and inorganic carbon were removed, will be referred to as 'base-treated.' Unless otherwise noted, 'assimilation' will refer to incorporation of label into this fraction. Homogenates of frozen tissues were extracted twice for $>12 \mathrm{~h}$ with $80 \%$ ethanol ( $\mathrm{EtOH}$ ) to separate low and high molecular weight components. The EtOH soluble fractions were pooled for each sample, evaporated at $60^{\circ} \mathrm{C}$, then treated with $\mathrm{NaOH}$ and $\mathrm{HCl}$. These fractions contained amino acids and other low molecular weight components and will be referred to as 'EtOH soluble.' The material that remained after EtOH treatment consisted of proteins and other high molecular weight compounds and will be referred to as 'EtOH insoluble.'

Determination of ${ }^{15} \mathrm{~N} /{ }^{14} \mathrm{~N}$ and ${ }^{13} \mathrm{C} /{ }^{12} \mathrm{C}$. An automated CHN analyzer (Roboprep-CN, Europa Scientific) interfaced with an isotope ratio mass spectrometer (IRMS; Tracermass, Europa Scientific) was used to determine ${ }^{15} \mathrm{~N} /{ }^{14} \mathrm{~N}$ and ${ }^{13} \mathrm{C} /{ }^{12} \mathrm{C}$ ratios as well as $\% \mathrm{~N}$ and $\% \mathrm{C}$ present in the samples (Owens 1988, Preston \& McMillan 1988, Brooks et al. 1989, Owens \& Rees 1989). Samples dried at $60^{\circ} \mathrm{C}$ were ground to a fine powder. Then 1 to $2 \mathrm{mg}$ quantities of sample were placed in tin capsules and weighed to $\pm 0.001 \mathrm{mg}$ with a Cahn electrobalance. The encapsulated samples were flash-combusted at $900^{\circ} \mathrm{C}$ and reduced over copper metal at $550^{\circ} \mathrm{C}$. The $\mathrm{N}_{2}$ and $\mathrm{CO}_{2}$ produced were separated by $\mathrm{GC}$ and then admitted directly to the IRMS for determination of ${ }^{15} \mathrm{~N} /{ }^{14} \mathrm{~N}$ and ${ }^{13} \mathrm{C} /{ }^{12} \mathrm{C}$. We routinely obtained precision of better than 0.01 at. $\%\left[{ }^{15} \mathrm{~N} \times(\right.$ total $\left.\mathrm{N}){ }^{-1} \times 100\right]$ for ${ }^{15} \mathrm{~N}$ and 0.001 at. $\%$ for ${ }^{13} \mathrm{C}$ and $\pm 0.1 \%$ for $\% \mathrm{C}$ and $\% \mathrm{~N}$ using reference materials 1572 , citrus leaves). Rates of assimilation are given as $\mu \mathrm{mol} \mathrm{g}^{-1}$ wet tissue $\mathrm{h}^{-1}$. The difference in at. \% of heavy isotope present in samples from tracer experiments and from mussels and gill pieces not exposed to labelled compounds was determined and then coverted to $\mu \mathrm{mol} \mathrm{g}{ }^{-1}$ wet tissue using $\%$ water and $\% \mathrm{C}$ or $\% \mathrm{~N}$ results. In general, isotope fractionation effects were not detectable, given the analytical precision of our determinations, or were negligible since $~ 100 \%$ ${ }^{15} \mathrm{~N}$ and ${ }^{13} \mathrm{C}$ substrates were used. Differences in isotopic natural abundance between different individuals and between pieces from the same gill were also not detectable and were negligible compared with the signal resulting from incorporation of labelled substrates.

Tissue ammonium determination. Tissues were dissected, then immediately frozen in liquid nitrogen and stored either in liquid nitrogen or at $-80^{\circ} \mathrm{C}$ until analysis. Tissues were homogenized in 5 volumes of $50 \%$ ethanol, then centrifuged (Millipore microfuge, $6400 \mathrm{rpm} ; 3$ to $5 \mathrm{~min}$ ) to remove solids. Supernatant of the tissue homogenate was analyzed for ammonium by FIA. The resulting homogenate ammonium concentrations are reported as $\mu$ mol ammonium $\mathrm{kg}^{-1}$ water present in tissue sample $(\mu \mathrm{M})$. 


\section{RESULTS}

\section{Assimilation of ${ }^{13} \mathrm{C}^{15} \mathrm{~N}$-glycine, ${ }^{15} \mathrm{NH}_{3}$, and ${ }^{15} \mathrm{NO}_{3}{ }^{-}$ and transfer of ${ }^{15} \mathrm{~N}$ and ${ }^{13} \mathrm{C}$ between gill and mantle tissue}

Symbiotic seep mytilids incorporated ${ }^{13} \mathrm{C}^{15} \mathrm{~N}$-glycine into both gill (symbiont-containing) and mantle (symbiont-free) tissue. Rates of ${ }^{15} \mathrm{~N}$ incorporation were 0.699 $\pm 0.309 \mu \mathrm{mol} \mathrm{g}^{-1} \mathrm{~h}^{-1}(\mathrm{SD} ; n=5)$ into gill tissue and 0.395 $\pm 0.089 \mu \mathrm{mol} \mathrm{g}^{-1} \mathrm{~h}^{-1}\left(\mathrm{SD}_{i} \mathrm{n}=4\right)$ into mantle tissue. The mean calculated ${ }^{15} \mathrm{~N}$ incorporation rate of $0.477 \mu \mathrm{mol}$ $\mathrm{g}^{-1} \mathrm{~h}^{-1}$ for whole mussels compares favorably with uptake rates of $0.56 \pm 0.22 \mu \mathrm{mol} \mathrm{g}{ }^{-1} \mathrm{~h}^{-1}\left(\mathrm{SD}_{i} \mathrm{n}=4\right)$ observed previously from initial concentrations of $10 \mu \mathrm{M}$ glycine (Lee et al. 1992). Rates of ${ }^{13} \mathrm{C}$ assimilation from ${ }^{13} \mathrm{C}^{15} \mathrm{~N}$-glycine were $0.459 \pm 0.230 \mu \mathrm{mol} \mathrm{g}^{-1} \mathrm{~h}^{-1}(\mathrm{SD} ; \mathrm{n}=$ $5)$ into gill tissue and $0.252 \pm 0.149 \mu \mathrm{mol} \mathrm{g}^{-1} \mathrm{~h}^{-1}(\mathrm{SD} ; \mathrm{n}=$ 4) into mantle tissue. The ratio of $\mathrm{C} / \mathrm{N}$ assimilation for the 2 tissues was $0.670 \pm 0.192(\mathrm{SD} ; \mathrm{n}=5)$ for gill and $0.618 \pm 0.353\left(\mathrm{SD}_{i} \mathrm{n}=4\right)$ for mantle. Since the ratio of ${ }^{13} \mathrm{C}$ to ${ }^{15} \mathrm{~N}$ in the ${ }^{13} \mathrm{C}^{15} \mathrm{~N}$-glycine used in the experiments was 1 , these results indicate that ${ }^{13} \mathrm{C}$ was metabolized and excreted to a greater degree than ${ }^{15} \mathrm{~N}$.

In an earlier report, we gave rates of assimilation for ${ }^{15} \mathrm{NH}_{3}$ and ${ }^{15} \mathrm{NO}_{3}{ }^{-}$by whole mussels collected in 1991 (Lee \& Childress 1994). Rates of ${ }^{15} \mathrm{NO}_{3}{ }^{-}$assimilation ex-
Table 1. Seep mytilid la. Assimilation of ${ }^{15} \mathrm{NH}_{3}$ and ${ }^{15} \mathrm{NO}_{3}^{-}$into gill and mantle tissue of mussels from different collections maintained in the laboratory $<7 \mathrm{~d}$. Incubations were 6 to $18 \mathrm{~h}$ for whole mussels and 3 to $6 \mathrm{~h}$ for excised gills in the presence of $50 \mu \mathrm{M}{ }^{15} \mathrm{~N}$ substrate and $200 \mu \mathrm{M}$ methane. Values given as mean $\pm \mathrm{SD}(\mathrm{n})$

\begin{tabular}{|c|c|c|}
\hline $\begin{array}{l}\text { Collection site } \\
\text { Tissue }\end{array}$ & \multicolumn{2}{|c|}{${ }^{15} \mathrm{~N}$ assimilation $\left(\mu \mathrm{mol} \mathrm{g}^{-1} \mathrm{~h}^{-1}\right)$} \\
\hline \multicolumn{3}{|l|}{ Bush Hill, 1991} \\
\hline Gill ${ }^{\text {a }}$ & $0.061 \pm 0.047(17)$ & $0.361 \pm 0.161(16)$ \\
\hline Mantle & $0.004 \pm 0.002(10)$ & $0.038 \pm 0.022(10)$ \\
\hline \multicolumn{3}{|c|}{ Bush Hill or Brine Pool, 1992} \\
\hline Gill & $0.059 \pm 0.031$ & \\
\hline Mantle & $0.013 \pm 0.009(5)$ & \\
\hline Excised gill & $0.248 \pm 0.075(8)$ & $0.395 \pm 0.115(25)$ \\
\hline \multicolumn{3}{|c|}{ Brine Pool, 1993} \\
\hline Gill & $0.396 \pm 0.184(5)^{\mathrm{b}}$ & $0.371 \pm 0.108(3)$ \\
\hline Mantle & $0.006 \pm 0.002(5)^{\mathrm{b}}$ & $0.006 \pm 0.004(3)$ \\
\hline \multicolumn{3}{|c|}{${ }^{2}$ Data from Lee \& Childress (1994) } \\
\hline \multicolumn{3}{|c|}{${ }^{\mathrm{b}}$ Incubation with $100 \mu \mathrm{M}^{15} \mathrm{NO}_{3}^{-}$} \\
\hline
\end{tabular}

hibited by seep mytilids are variable (Lee \& Childress unpubl.), and in the present study, results were used from incubations in which mussels and excised gills exhibited moderate to high rates of ${ }^{15} \mathrm{NO}_{3}{ }^{-}$assimilation.

Table 2. Seep mytilid Ia. Incorporation of ${ }^{15} \mathrm{~N}$ and ${ }^{13} \mathrm{C}$ into fractionated tissue samples from intact mussels (1991 collection) incubated with $50 \mu \mathrm{M}{ }^{15} \mathrm{NH}_{4}$ with and without 100 to $200 \mu \mathrm{M}^{13} \mathrm{CH}_{4}$ for $12 \mathrm{~h} \mathrm{~g}^{-1}$ refers to unfractionated tissue weight. Values given as mean $\pm \mathrm{SD}(\mathrm{n})$. Base-treated refers to samples treated with $\mathrm{NaOH}$ and acid to remove ammonium and inorganic carbon. EtOH soluble fraction contains low molecular weight organic compounds; EtOH insoluble fraction contains high molecular weight compounds

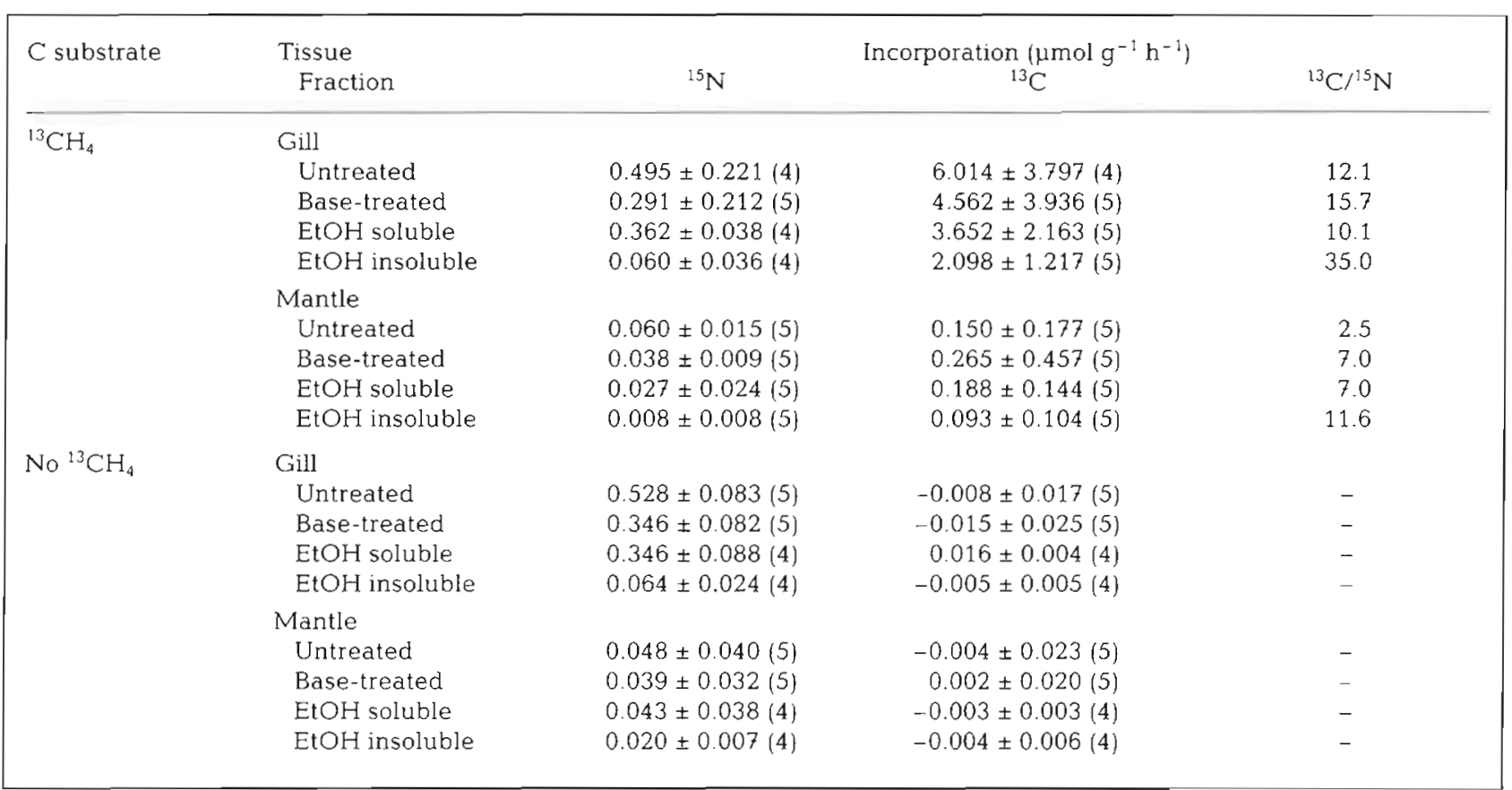


${ }^{15} \mathrm{~N}$ label from ${ }^{15} \mathrm{NH}_{3}$ and ${ }^{15} \mathrm{NO}_{3}{ }^{-}$incubations was incorporated at much higher rates in the gill compared with mantle (Table 1). From these results, and based on our measurement of average gill weight as $28 \%$ of total tissue weight, the proportion of label in gill and mantle tissue was calculated. $74 \%$ of the ${ }^{15} \mathrm{~N}$ label was present in the gill tissue following ${ }^{15} \mathrm{NH}_{3}$ incubations (Bush Hill, 1991 collection), which is similar to results for ${ }^{13} \mathrm{CH}_{4}$ assimilation by these same mussels in which $80 \%$ of the label was present in the gills (Table 2). For ${ }^{15} \mathrm{NO}_{3}{ }^{-}$incubations of laboratory maintained mussels collected from the Brine Pool (laboratory maintained $3 \mathrm{~d}$ ), $96 \%$ of the ${ }^{15} \mathrm{~N}$ (Table 1 ) and $98 \%$ of the ${ }^{13} \mathrm{C}$ label was present in the gill tissues. To investigate transfer of ${ }^{15} \mathrm{~N}$ from gill to mantle tissue, pulse-chase experiments with ${ }^{15} \mathrm{NH}_{3}$ and ${ }^{13} \mathrm{CH}_{4}$ were conducted using mussels collected in 1991. Following an $11 \mathrm{~h}$ pulse, a slight loss of ${ }^{15} \mathrm{~N}$ and ${ }^{13} \mathrm{C}$ from the gill tissues was observed during the chase period (109 h) but no increase was observed in the mantle tissue (Fig. 1a, b).

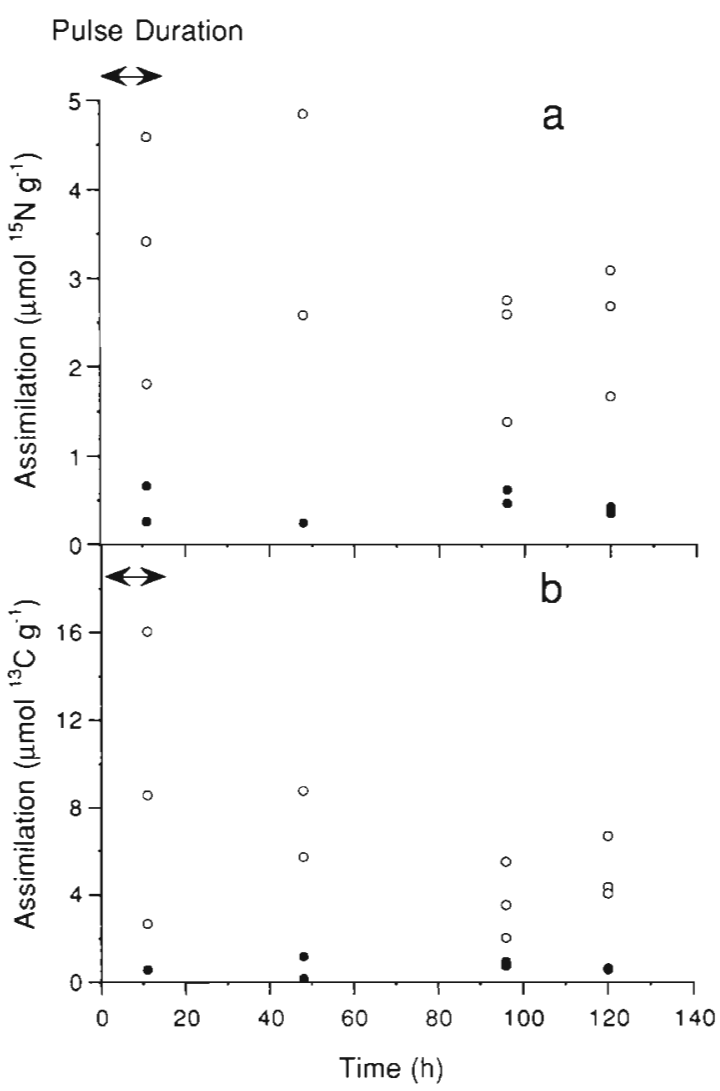

Fig. 1. Seep mytilid Ia. Pulse-chase incubation of symbiotic laboratory-maintained mussels from 1991 collection. Mussels were exposed to $50 \mu \mathrm{M}{ }^{15} \mathrm{NH}_{4}$ and $200 \mu \mathrm{M}{ }^{13} \mathrm{CH}_{4}$ for $11 \mathrm{~h}$. (a) Assimilation of ${ }^{15} \mathrm{NH}_{4}$ into base-treated fraction. (b) Assimilation of ${ }^{13} \mathrm{CH}_{4}$ into base-treated fraction. Values are from single measurements. $(\bullet)$ Gill tissue, $(0)$ mantle tissue

\section{Fate of incorporated ${ }^{13} \mathrm{CH}_{4}$ and ${ }^{15} \mathrm{NH}_{3}$}

Around $40 \%$ of the ${ }^{15} \mathrm{~N}$ label and $25 \%$ of the ${ }^{13} \mathrm{C}$ label present in untreated gill tissue from mussels incubated for $12 \mathrm{~h}$ in the presence of ${ }^{13} \mathrm{CH}_{4}$ and ammonium was lost following treatment with $\mathrm{NaOH}$ and $\mathrm{HCl}$, indicating that a substantial proportion of label was present as ${ }^{15} \mathrm{NH}_{3}$ and ${ }^{13} \mathrm{CO}_{2}$ (Table 2). From these results we estimate that $2.4 \mathrm{mM}^{15} \mathrm{NH}_{3}$ and $17.4 \mathrm{mM}$ ${ }^{13} \mathrm{CO}_{2}$ were present in these samples. Treatment of mantle samples resulted in a slight loss of ${ }^{15} \mathrm{~N}$, but no loss of ${ }^{13} \mathrm{C}$ was detected

The largest proportion of ${ }^{15} \mathrm{~N}$ and ${ }^{13} \mathrm{C}$ was present in the EtOH soluble fraction of gills $(73$ and $61 \%$ respectively). This fraction contains amino acids and the ratio of $\mathrm{C} / \mathrm{N}$ assimilated into this fraction was 10.1 (Table 2). Similarly, the largest proportion of label was in the EtOH soluble fraction of mantle tissue with a $\mathrm{C} / \mathrm{N}$ assimilation ratio of 7 . The EtOH insoluble fraction of gill tissue contained only $12 \%$ of the ${ }^{15} \mathrm{~N}$ label compared with $35 \%$ of the ${ }^{13} \mathrm{C}$ label. The $\mathrm{C} / \mathrm{N}$ assimilation ratio for this fraction was 35 .

\section{Assimilation of excretory ammonium}

If ammonium from host excretion is assimilated, then rates of assimilation of exogenous ${ }^{15} \mathrm{NH}_{3}$ may underestimate the actual rate of ammonium assimilation. Assuming that exogenous and excretory ammonium act as a single pool, then the percentage of ammonium present as ${ }^{15} \mathrm{NH}_{3}$ can be used to determine the actual rate of ammonium assimilation. To estimate the relative abundance of ${ }^{15} \mathrm{NH}_{3}$ and ${ }^{14} \mathrm{NH}_{3}$, mussels were incubated in 10 to $1000 \mu \mathrm{M}{ }^{15} \mathrm{NH}_{3}$ for $6 \mathrm{~h}$. Gill tissues were analyzed for ${ }^{15} \mathrm{NH}_{3}$ by IRMS. Labelled and unlabelled ammonium $\left({ }^{15} \mathrm{NH}_{3}+{ }^{14} \mathrm{NH}_{3}\right)$ were determined in EtOH extracts of tissues by FIA. Results from these experiments are shown in Fig. 2. ${ }^{15} \mathrm{NH}_{3}$ concentration correlated with ${ }^{15} \mathrm{NH}_{3}+{ }^{14} \mathrm{NH}_{3}$ concentration. The slope of the relation was $0.67 \pm 0.28(95 \%$ confidence interval for slope), indicating that the internal $\sum \mathrm{NH}_{3}$ pool was $67 \%{ }^{15} \mathrm{NH}_{3}$ and therefore assimilation of ${ }^{15} \mathrm{NH}_{3}$ from the medium comprised around two-thirds of the actual ammonium assimilation (Fig. 2). Thus $\mathrm{C} / \mathrm{N}$ assimilation ratios for ammonium assimilation based on ${ }^{15} \mathrm{NH}_{3}$ assimilation rates may be over-estimates. For example, the $\mathrm{C} / \mathrm{N}$ assimilation ratio of 12.1 observed for whole mussels incubated with ${ }^{15} \mathrm{NH}_{3}$ and ${ }^{13} \mathrm{CH}_{4}$ corresponds to a ratio of 8.1 when excretory ammonium is considered. Unless otherwise stated, $\mathrm{C} / \mathrm{N}$ assimilation ratios given are the raw ratios, uncorrected for the problem of source pools. The $\mathrm{C} / \mathrm{N}$ ratio of gill tissue was $4.23 \pm 0.56(\mathrm{SD}, \mathrm{n}=27)$. This value is representative of values that are exhibited by mussels from differ- 


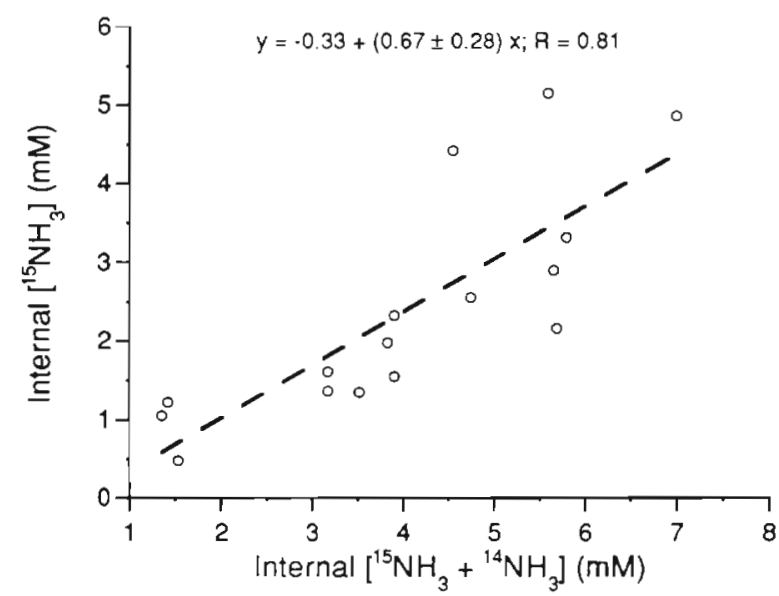

Fig. 2. Seep mytilid la. Proportion of gill tissue ammonium that is ${ }^{15} \mathrm{NH}_{3}$ in symbiotic mussels collected in 1992. Values are from single measurements

ent collections and under different maintenance conditions. The high $\mathrm{C} / \mathrm{N}$ assimilation ratio 12.1 (corrected to 8.1) exhibited by whole gill tissue of these mussels indicates that $\mathrm{C}$ is assimilated in excess of $\mathrm{N}$ needs

\section{Relation between ${ }^{13} \mathrm{CH}_{4}$ and $\mathrm{N}$ assimilation}

Variability in ${ }^{13} \mathrm{CH}_{4},{ }^{15} \mathrm{NH}_{3}$, and ${ }^{15} \mathrm{NO}_{3}{ }^{-}$assimilation rates was observed among individual mussels. ${ }^{15} \mathrm{NH}_{3}$ and ${ }^{15} \mathrm{NO}_{3}{ }^{-}$assimilation into gill tissue was strongly correlated with ${ }^{13} \mathrm{CH}_{4}$ assimilation (Fig. $3 a$ to $\mathrm{c}$ ). The inverse of the slopes of these regression lines, which is one measure of the relation between $\mathrm{C}$ and $\mathrm{N}$ assimilation, was 20 for ${ }^{15} \mathrm{NH}_{3}$-incubated mussels that exhibited a mean $\mathrm{C} / \mathrm{N}$ assimilation ratio of 12.1 (Fig. $3 \mathrm{a}$ ), 4.3 for another set of ${ }^{15} \mathrm{NH}_{3}$ incubated mussels that exhibited a mean $\mathrm{C} / \mathrm{N}$ assimilation ratio of 2.1 (Fig. $3 \mathrm{~b}$ ), and 7.7 for ${ }^{15} \mathrm{NO}_{3}{ }^{-}$incubated mussels that exhibited a mean $\mathrm{C} / \mathrm{N}$ assimilation ratio of 12.7 (Fig, $3 \mathrm{C}$ ). Although the strong correlation between ${ }^{13} \mathrm{CH}_{4}$ and $\mathrm{N}$ assimilation suggests that $\mathrm{N}$ assimilation is dependent on ${ }^{13} \mathrm{CH}_{4}$ assimilation, we believe that they actually co-vary with some other factor such as condition or symbiont population size. A variety of direct tests, as described below, indicated that $\mathrm{N}$ assimilation and ${ }^{13} \mathrm{CH}_{4}$ assimilation are independent of each other.

The rate of $\mathrm{N}$ assimilation was not dependent on methanotrophy. For example, $\mathrm{C} / \mathrm{N}$ assimilation ratios differed between experiments involving intact mussels (Fig. 3a, b). Intact mussels incubated without methane in the medium exhibited rates of $\mathrm{N}$ assimilation that were indistinguishable from mussels incubated with ${ }^{13} \mathrm{CH}_{4}$ (Table 2). Rates of $\mathrm{N}$ assimilation into the various chemical fractions (organic, EtOH soluble and insoluble) were also indistinguishable (Table 2). Treatment

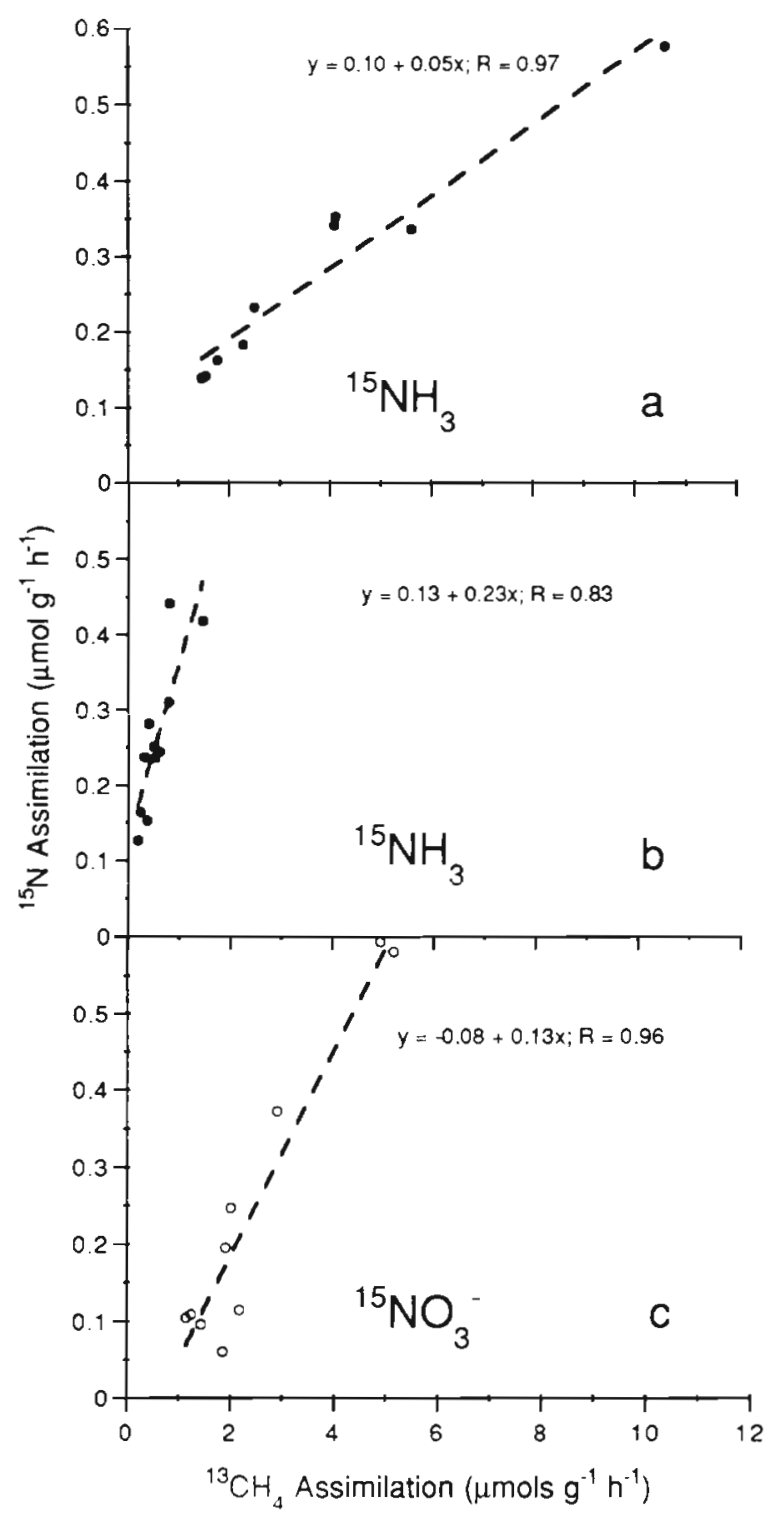

Fig. 3. Seep mytilid la. ${ }^{15} \mathrm{~N}$ assimilation rate vs ${ }^{13} \mathrm{CH}_{4}$ assimilation rate exhibited by gills from whole seep mytilid la incubations. Mussels from 1992 collection incubated with $50 \mu \mathrm{M}^{15} \mathrm{NH}_{3}$ and $200 \mu \mathrm{M}^{13} \mathrm{CH}_{4}$ for (a) 12 or $24 \mathrm{~h}$ or (b) $12 \mathrm{~h}$. Mussels from Brine Pool collected in 1993 incubated with $50 \mu \mathrm{M}^{15} \mathrm{NO}_{3}{ }^{-}$and $200 \mu \mathrm{M}^{13} \mathrm{CH}_{4}$ for (c) $7 \mathrm{~h}$. Values are from single measurements

of excised gill pieces with acetylene $\left(\mathrm{C}_{2} \mathrm{H}_{2}\right)$, which completely inhibited ${ }^{13} \mathrm{CH}_{4}$ assimilation, had no effect on the rate of ${ }^{15} \mathrm{NO}_{3}{ }^{-}$or ${ }^{15} \mathrm{NH}_{3}$ assimilation (Table 3 ).

Methane assimilation was not dependent on $\mathrm{N}$ assimilation. In excised gill ${ }^{13} \mathrm{CH}_{4} /{ }^{15} \mathrm{~N}$ incubations where ${ }^{15} \mathrm{~N}$ assimilation was increased by increasing the concentration of ${ }^{15} \mathrm{~N}$ substrate in the medium, no relation was observed between ${ }^{15} \mathrm{~N}$ and ${ }^{13} \mathrm{C}$ assimilation rates (Fig. 4a, b). If methanotrophy directly supports $\mathrm{N}$ assimilation, then increased rates of $\mathrm{N}$ assimi- 
Table 3. Seep mytilid Ia. Assimilation of ${ }^{15} \mathrm{~N}$ and ${ }^{13} \mathrm{C}$ into the base-treated fraction of excised seep mytilid gills from 1991 collection. Incubations performed under conditions of $50 \mu \mathrm{M}$ ${ }^{15} \mathrm{~N}$ substrate and $200 \mu \mathrm{M}{ }^{13} \mathrm{CH}_{4}$. Acetylene $\left(\mathrm{C}_{2} \mathrm{H}_{2}\right)$ was used in some treatments to inhibit methanotrophy. Boldface denotes treatments significantly different from ${ }^{15} \mathrm{NH}_{3}{ }^{13} \mathrm{CH}_{4}$ treatment (Wilcoxon signed-rank test; $p<0.05$ ). Values given as mean $\pm \mathrm{SD}(\mathrm{n})$

\begin{tabular}{|c|c|c|}
\hline Treatment & \multicolumn{2}{|c|}{$\begin{array}{l}\text { Assimilation }\left(\mu \mathrm{mol} \mathrm{g}^{-1} \mathrm{~h}^{-1}\right) \\
{ }^{15} \mathrm{~N}\end{array}$} \\
\hline \multicolumn{3}{|l|}{${ }^{15} \mathrm{NH}_{3}$} \\
\hline${ }^{13} \mathrm{CH}_{4}$ & $0.232 \pm 0.211(6)$ & $0.433 \pm 0.259(6)$ \\
\hline $\mathrm{C}_{2} \mathrm{H}_{2}+{ }^{13} \mathrm{CH}_{4}$ & $0.162 \pm 0.036(6)$ & $0.017 \pm 0.023(6)$ \\
\hline \multicolumn{3}{|l|}{${ }^{15} \mathrm{NO}_{3}^{-}$} \\
\hline${ }^{13} \mathrm{CH}_{4}$ & $0.064 \pm 0.030[6]$ & $0.399 \pm 0.225(6)$ \\
\hline $\mathrm{C}_{2} \mathrm{H}_{2}+{ }^{13} \mathrm{CH}_{4}$ & $0.059 \pm 0.015(5)$ & $0.002 \pm 0.019(5)$ \\
\hline${ }^{13} \mathrm{CH}_{4}+{ }^{14} \mathrm{NH}_{3}$ & $0.028 \pm 0.021(6)^{a}$ & $0.371 \pm 0.282(6)$ \\
\hline \multicolumn{3}{|c|}{$\begin{array}{l}{ }^{a} \text { Significantly different from }{ }^{15} \mathrm{NO}_{3}-{ }^{-13} \mathrm{CH}_{4} \text { treatment } \\
\text { (Wilcoxon signed-rank test; } \mathrm{p}<0.075 \text { ) }\end{array}$} \\
\hline
\end{tabular}

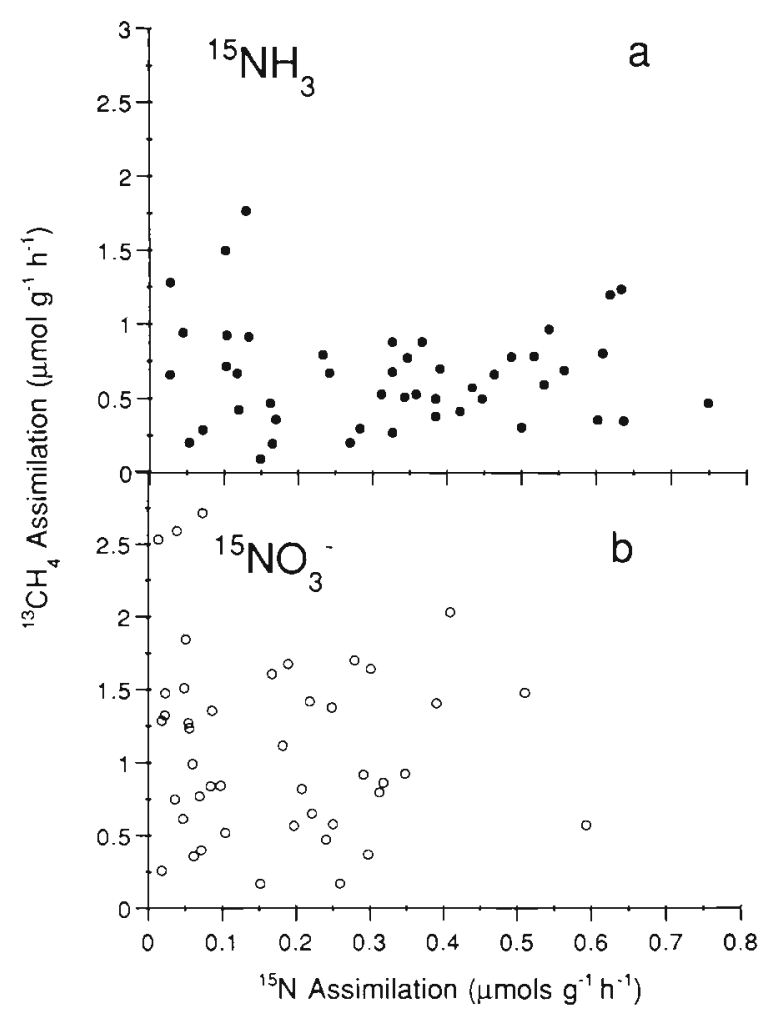

Fig. 4. Seep mytilid la. ${ }^{13} \mathrm{CH}_{4}$ assimilation vs ${ }^{15} \mathrm{~N}$ assimilation exhibited by excised gills of seep mytilid Ia from 1991 collection. (a) Ammonium incubated gills; gills were incubated for 3 to $6 \mathrm{~h}$. (b) Nitrate incubated gills; gills were incubated for $6 \mathrm{~h}$. All incubations were in seawater containing 160 to $200 \mu \mathrm{M}$ labelled or unlabelled methane using mussels from the 1992 collection. Values are from single measurements lation might be accompanied by stimulation of ${ }^{13} \mathrm{CH}_{4}$ assimilation provided that methane is not limiting.

We characterized the time courses of ${ }^{13} \mathrm{CH}_{4}$ and ${ }^{15} \mathrm{~N}$ assimilation into excised gills by incubating pieces with ${ }^{15} \mathrm{NH}_{3}$ or ${ }^{15} \mathrm{NO}_{3}{ }^{-}$and ${ }^{13} \mathrm{CH}_{4}$ for up to $48 \mathrm{~h}$ (Fig. $5 \mathrm{a}$, b). If methanotrophy supports $\mathrm{N}$ assimilation directly, then the ratio of $\mathrm{C} / \mathrm{N}$ assimilated should be constant over time. This was not the case. The ratio of $\mathrm{C} / \mathrm{N}$ assimilated during different time intervals in ${ }^{15} \mathrm{NH}_{3}$ incubations increased with time from 3 to 5.5 (Fig. $5 \mathrm{a}$ ). The opposite was observed in ${ }^{15} \mathrm{NO}_{3}{ }^{-}$incubations, with the ratio of $\mathrm{C} / \mathrm{N}$ assimilation decreasing from around 26 to 7 (Fig. 5b).

Since methane and inorganic $\mathrm{N}$ assimilation were decoupled, under some conditions excess ${ }^{13} \mathrm{CH}_{4}$ assimilation was observed. Conversely, inorganic $\mathrm{N}$ assimilation in excess of demands due to methane were also observed. Such 'luxury consumption' of $N$, in which $\mathrm{C} / \mathrm{N}$ assimilation ratios are less than 4.2 , were exhibited initially in the ${ }^{15} \mathrm{NH}_{3}$ time-course experiment and were also induced by increasing the concentration of

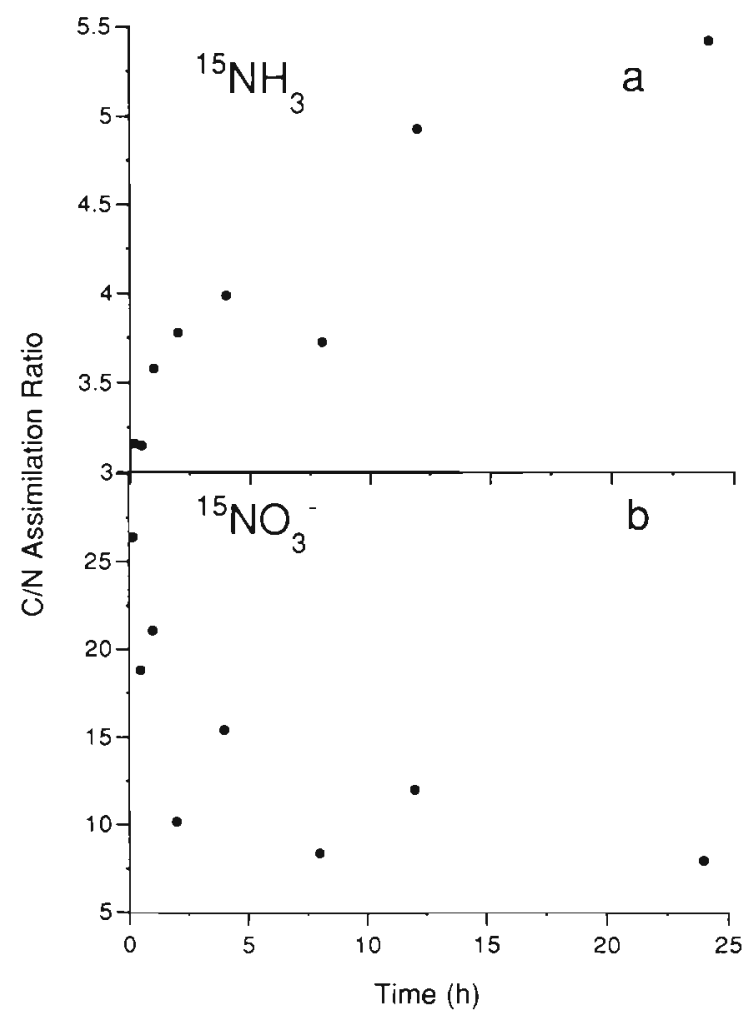

Fig. 5. Seep mytilid Ia. Time-course of ${ }^{15} \mathrm{~N}$ and ${ }^{13} \mathrm{C}$ assimilation into base-treated fraction by excised seep mytilid la gills. (a) Ratio of $\mathrm{C} / \mathrm{N}$ assimilation vs time for ammonium incubated gills. (b) Ratio of $\mathrm{C} / \mathrm{N}$ assimilation vs time for nitrate incubated gills. Gills from 1992 collection incubated in $100 \mu \mathrm{M}{ }^{15} \mathrm{~N}$ substrate and 160 to $200 \mu \mathrm{M}^{13} \mathrm{CH}_{4}$. Values are from single measurements 


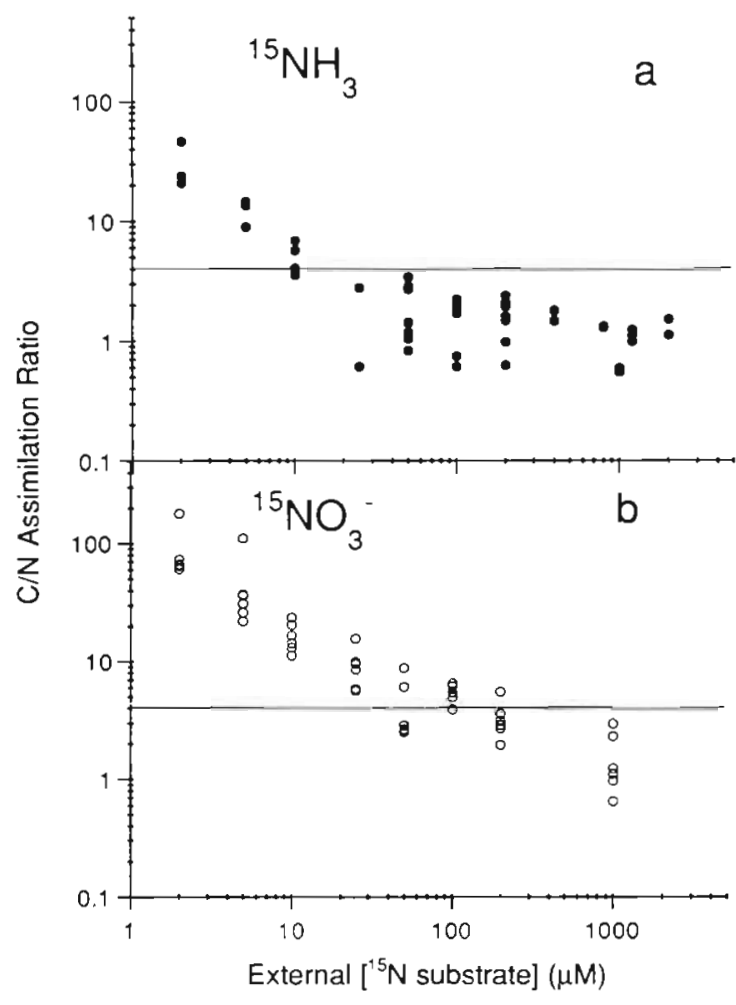

Fig. 6. Seep mytilid Ia. C/N assimilation ratio of excised seep mytilid la gills vs concentration of $N$ substrate. (a) Arnmonium incubated gills from Fig. 4a. (b) Nitrate incubated gills from Fig. $4 \mathrm{~b}$. Values are from single measurements

${ }^{15} \mathrm{NH}_{3}$ or ${ }^{15} \mathrm{NO}_{3}{ }^{-}$in the medium. When concentrations of ${ }^{15} \mathrm{NH}_{3}$ in the medium were increased above $10 \mu \mathrm{M}$, $\mathrm{C} / \mathrm{N}$ assimilation ratios below 4 were observed and ranged below 1 (Fig. 6a). Concentrations of ${ }^{15} \mathrm{NO}_{3}{ }^{-}$ above 50 to $200 \mu \mathrm{M}$ also resulted in $\mathrm{C} / \mathrm{N}$ assimilation ratios below 4 (Fig. 6b).

\section{DISCUSSION}

\section{Assimilation of organic $\mathbf{N}$}

Heterotrophic acquisition of $\mathrm{C}$ and $\mathrm{N}$ can potentially make a large contribution to seep mytilid nutrition, but the importance of these sources relative to methane and inorganic $\mathrm{N}$ is difficult to assess without good measurements of dissolved and particulate organic material in the immediate vicinity of mussels. The rates of filter-feeding that are observed indicate that the $C$ 'maintenance' needs of the association can be satisfied when $>10^{6}$ bacteria cells are present in the water column (Page et al. 1990). However, the abundance of particulate material and its $\mathrm{C} / \mathrm{N}$ ratio around mussels has not been studied. The rates of uptake and assimi- lation that are observed for amino acids are quite high. Rates of glycine uptake from $10 \mu \mathrm{M}$ initial concentrations are comparable to the highest rates of ammonium uptake that we have measured (Lee et al. 1992). In the present study, the rate of $\mathrm{C}$ assimilation from $50 \mu \mathrm{M}$ ${ }^{13} \mathrm{C}^{15} \mathrm{~N}$-glycine incubations was $0.620 \mu \mathrm{mol} \mathrm{C} \mathrm{g}^{-1} \mathrm{~h}^{-1}$ for the whole mussel, which is considerably less than the mean rate of ${ }^{13} \mathrm{CH}_{4}$ assimilation of $1.79 \mu \mathrm{mol} \mathrm{C} \mathrm{g}^{-1}$ $\mathrm{h}^{-1}$ observed for ${ }^{15} \mathrm{NH}_{3}$ incubated mussels. Methane assimilation rates of up to $5 \mu \mathrm{mol} \mathrm{C} \mathrm{g}^{-1} \mathrm{~h}^{-1}$ have been observed previously (Kochevar et al. 1992). The rate of $\mathrm{N}$ assimilation from $50 \mu \mathrm{M}{ }^{13} \mathrm{C}^{15} \mathrm{~N}$-glycine incubations was $0.477 \mu \mathrm{mol} \mathrm{Ng}^{-1}$ whole mussel $\mathrm{h}^{-1}$. Rates of ${ }^{15} \mathrm{NH}_{3}$ assimilation exhibited by mussels from Table 2 were $0.182 \mu \mathrm{mol} \mathrm{N} \mathrm{g}^{-1}$ whole mussel $\mathrm{h}^{-1}$. However, the rates of amino acid uptake likely overestimate the rates in situ since the concentrations of individual amino acids in samples overlying mussels were ail below $1 \mu \mathrm{M}$ (Lee et al. 1992). These samples were likely diluted by ambient water and concentrations of individual amino acids may actually be higher. Determination of environmental conditions encountered by the mussels is difficult due to the likelihood of steep chemical gradients resulting from mixing of seep effluent with ambient bottom water. Improved sampling technologies will facilitate better characterization.

\section{Host or symbiont mediated $\mathrm{N}$ assimilation?}

Our results indicate that inorganic $N$ is not assimilated in tissues that are free from symbionts. ${ }^{15} \mathrm{~N}$ from ${ }^{15} \mathrm{NH}_{3}$ and ${ }^{15} \mathrm{NO}_{3}{ }^{-}$appeared to a much greater degree in gill tissue, with only a low level of label present in the mantle tissue. ${ }^{15} \mathrm{~N}$ was distributed between gill and mantle tissue in a similar fashion to ${ }^{13} \mathrm{C}$ from ${ }^{13} \mathrm{CH}_{4}$, which is assimilated only by the symbionts. Isolated gills assimilated ${ }^{15} \mathrm{NH}_{3}$ at rates that were comparable to rates exhibited by gills in intact mussels. Although it is possible that ${ }^{15} \mathrm{~N}$ present in mantle tissue was assimilated there, these rates are low compared with gill tissue. Furthermore, nitrate reductase activity was not detected in mantle tissue and glutamine synthetase activity was considerably lower in mantle compared with gill tissue (Lee \& Childress unpubl.).

Within the gills, our results are inconclusive with regard to whether assimilation occurs in the host tissue, symbionts, or both. Many of our findings support symbiont-mediated assimilation. The distribution of ${ }^{15} \mathrm{~N}$ was similar to the distribution of symbiont-assimilated ${ }^{13} \mathrm{C}$ from ${ }^{13} \mathrm{CH}_{4}$. Ingestion of ${ }^{14} \mathrm{C}$-labelled bacteria (Page et al. 1990 ) and ${ }^{13} \mathrm{C}^{15} \mathrm{~N}$-glycine resulted in the appearance of substantial amounts of label in the mantle tissue, indicating that processes that clearly involve host participation result in uniformly distributed $\mathrm{C}$ and 
$\mathrm{N}$. Variation among individuals in ability to assimilate ${ }^{13} \mathrm{CH}_{4}$ correlated with the $\mathrm{N}$ assimilation rate. Although inorganic $\mathrm{N}$ and methane assimilation are not directly linked, methane and inorganic $\mathrm{N}$ assimilation ability may co-vary as a function of symbiont population size. However, given that ammonium assimilation is likely supported by carbon reserves, and that ammonium assimilation enzymes are present in host tissues (Lee \& Childress unpubl.), assimilation of ammonium may be facilitated by the host.

\section{Evidence for $\mathbf{N}$ assimilation supported by $\mathrm{C}$ reserves and its implications}

In the present study, we demonstrate that $\mathrm{N}$ assimilation is not directly dependent on methanotrophy and that assimilation can be supported entirely from stored reduced carbon. There is however, a long-term dependence on methanotrophy since aposymbiotic mussels do not take up ammonium (Lee et al. 1992). C used to assimilate inorganic $N$ may be derived entirely or in part from methanotrophy. In tissue fractionations, we observed a disproportionate amount of ${ }^{13} \mathrm{C}$ label in the $\mathrm{EtOH}$ insoluble fraction of mussel gills. This may reflect incorporation of methane into carbon-rich storage products such as polyhydroxybutyrate (Anthony 1.982).

The utilization of carbon storage products in the assimilation of inorganic $\mathrm{N}$ is likely important in facilitating luxury consumption of $\mathrm{N}$ by seep mytilids. $\mathrm{C}$ from methane was not directly required for assimilation of inorganic $\mathrm{N}$. The rates of ${ }^{15} \mathrm{NH}_{3}$ assimilation and distribution into various chemical fractions was similar between mussels incubated with and without ${ }^{13} \mathrm{CH}_{4}$ (Table 2). Acetylene inhibition of methanotrophy in excised gills had no effect on inorganic $\mathrm{N}$ assimilation (Table 3). Conversely, increasing rates of $N$ assimilation of excised gills by increasing $\mathrm{N}$ substrate concentration in the medium did not stimulate ${ }^{13} \mathrm{CH}_{4}$ assimilation. Thus, methane and inorganic $\mathrm{N}$ assimilation are not coupled. The ratio of $\mathrm{C} / \mathrm{N}$ assimilation for methane and inorganic $\mathrm{N}$ was found to vary considerably among treatments. In ${ }^{13} \mathrm{C}^{15} \mathrm{~N}$-glycine incubations, the finding that ${ }^{15} \mathrm{~N}$ is retained to a greater degree than ${ }^{13} \mathrm{C}$ indicates that sources of carbon other than from glycine are utilized to assimilate the amino N. The ability to utilize stored carbon and the decoupling of $\mathrm{C}$ and $\mathrm{N}$ assimilation can result in $\mathrm{C} / \mathrm{N}$ assimilation in a ratio below 4.2 (luxury consumption). In the presence of 160 to $200 \mu \mathrm{M}{ }^{13} \mathrm{CH}_{4}$, luxury consumption was exhibited under conditions of $>10 \mu \mathrm{M}{ }^{15} \mathrm{NH}_{3}$ or $>50$ to $200 \mathrm{\mu M}^{15} \mathrm{NO}_{3}{ }^{-}$. The lowest ratios of $\mathrm{C} / \mathrm{N}$ assimilation were around 1 , indicating utilization of carbon reserves and/or possible preferential production of $\mathrm{N}$ rich amino acids such as asparagine $(\mathrm{C} / \mathrm{N}=2)$ or arginine $(\mathrm{C} / \mathrm{N}=1.5)$.

Depending on environmental conditions, assimilated $\mathrm{N}$ may exceed that required for growth $(\mathrm{C} / \mathrm{N}$ assimilation $<4,2$ ) or assimilated $C$ may exceed that required for growth (C/N assimilation $>4.2)$. Excess $\mathrm{C}$ assimilation may reflect $\mathrm{N}$ limitation. However, this depends on the fate of symbiont assimilated $\mathrm{C}$ within the host tissues which is presently unknown. During the relatively short incubation periods in the present study, there was likely little transfer of symbiont derived $C$ to host tissues. If symbiont derived $\mathrm{C}$ is primarily respired, then excess $C$ assimilation does not necessarily reflect $\mathrm{N}$ limitation of the association as a whole.

\section{Estimates of $\mathrm{C}$ and $\mathrm{N}$ assimilation rates in situ - evidence for excess assimilation of $\mathrm{C}$}

Nitrate and ammonium are both present in the seep mytilid environment. In water overlying mussels, nitrate ranges from 9.4 to $41.0 \mu \mathrm{M}$ while ammonium ranges from 1.6 to $13 \mu \mathrm{M}$ although concentrations as high as $9.4 \mathrm{mM}$ are observed in brine near mussels (Lee \& Childress 1994). The rate of inorganic nitrogen assimilation at a given concentration of ammonium and nitrate in the environment can be estimated from assimilation rate vs source concentration results (Lee \& Childress unpubl.). The dependence of ${ }^{15} \mathrm{NH}_{3}$ assimilation ( $\mu \mathrm{mol} \mathrm{g}{ }^{-1}$ whole mussel $\mathrm{h}^{-1}$ ) on ${ }^{15} \mathrm{NH}_{3}$ concentration $(\mu \mathrm{M})$ in the environment exhibited by laboratory maintained mussels collected at the brine pool was:

$$
\begin{gathered}
\text { Ammonium assimilation }=0.036 \times\left[\sum \mathrm{NH}_{3}\right]^{0.25} \\
\left(\mathrm{r}^{2}=0.79\right) .
\end{gathered}
$$

The dependence of ${ }^{15} \mathrm{NO}_{3}{ }^{-}$assimilation rate by excised gills (converted to $\mu \mathrm{mol} \mathrm{g}$ whole mussel ${ }^{-1} \mathrm{~h}^{-1}$ ) on ${ }^{15} \mathrm{NO}_{3}{ }^{-}$concentration $(\mu \mathrm{M})$ was:

$$
\begin{aligned}
& \text { Nitrate assimilation }=0.007 \times\left[\mathrm{NO}_{3}\right]^{0.42} \\
& \qquad\left(\mathrm{r}^{2}=0.43\right) .
\end{aligned}
$$

The presence of ${ }^{14} \mathrm{NH}_{3}$ reduced the rate of ${ }^{15} \mathrm{NO}_{3}{ }^{-}$ assimilation by excised gills. The relation between ammonium concentration and the \% maximum nitrate assimilation was:

$$
\% \text { maximum }=100 \times\left[\sum \mathrm{NH}_{3}\right]^{-0.56}\left(\mathrm{r}^{2}=0.74\right) .
$$

These equations were chosen based on fit and do not imply possible mechanisms. By combining these equations we obtain the following:

Total $\mathrm{N}$ assimilation $=\left(0.036 \times\left[\sum \mathrm{NH}_{3}\right]^{025}\right)$

$$
+\left(0.007 \times\left[\mathrm{NO}_{3}\right]^{0.42} \times\left[\sum \mathrm{NH}_{3}\right]^{-0.56}\right) \text {. }
$$

The isolines for nitrate and ammonium concentrations that result in a given value of total $N$ assimilation 

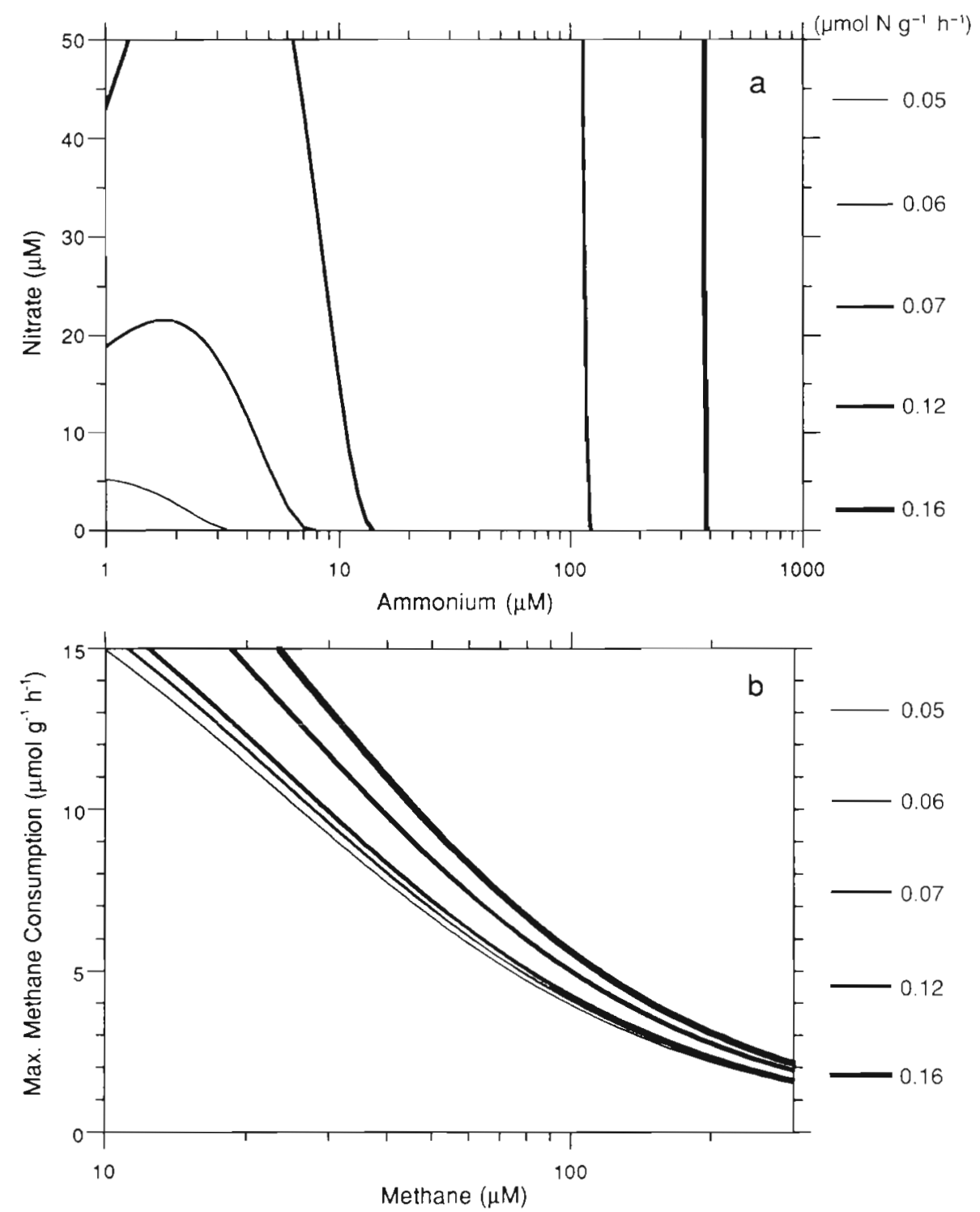

Fig. 7. Seep mytilid la. (a) Relationships between rate of total inorganic $N$ assimilation $v s$ ammonium and nitrate in the medium. Isolines given for various rates of $\mathrm{N}$ assimilation. (b) Rate of $\mathrm{C}$ assimilation that results in $\mathrm{C} / \mathrm{N}$ balance vs methane concentration and maximum methane consumption rate. Isolines given for methane assimilation resulting in $\mathrm{C} / \mathrm{N}$ balance for values of $\mathrm{N}$ assimilation given in (a)

(0.05 to $\left.0.16 \mu \mathrm{mol} \mathrm{g}^{-1} \mathrm{~h}^{-1}\right)$ are given in Fig. 7a. From this figure it is apparent that, when ammonium concentrations are low $(\leq 1 \mu M)$ and maximum nitrate concentrations are exhibited, rates of total $\mathrm{N}$ assimilation as high as $0.07 \mu \mathrm{mol} \mathrm{g}^{-1} \mathrm{~h}^{-1}$ are possible. The same rate is possible from ammonium alone at concentrations of $20 \mu \mathrm{M}$. From the shape of the 0.06 and $0.07 \mu \mathrm{mol} \mathrm{g}^{-1} \mathrm{~h}^{-1}$ isolines, it is apparent that, according to the relations derived in our studies, the reduction in $\mathrm{N}$ assimilation due to the effect of ammonium on nitrate assimilation is not offset by a concomitant increase in ammonium assimilation rate. For example, higher nitrate concentrations are required to achieve a rate of $0.06 \mu \mathrm{mol} \mathrm{g}^{-1} \mathrm{~h}^{-1}$ if ammonium concentration is increased from 1 to $3 \mu \mathrm{M}$. Once ammonium concentration is greater than 10 to $20 \mu \mathrm{M}$, the contribution to total $\mathrm{N}$ assimilation by nitrate at environ- mentally realistic concentrations $(<50 \mu \mathrm{M}$ nitrate) is negligible.

From results obtained for methane consumption by whole mussels measured by Kochevar et al. (1992), it is possible to calculate the conditions required for methane assimilation to equal 4.2 times a given rate of $\mathrm{N}$ assimilation (i.e. $\mathrm{C}$ and $\mathrm{N}$ balance). The relation between methane consumption ( $\mu \mathrm{mol} \mathrm{g}^{-1} \mathrm{~h}^{-1}$ ) and methane concentration ( $\mu \mathrm{M})$ up to $300 \mu \mathrm{M}$, where it is observed to saturate, is:

$$
\begin{aligned}
& \mathrm{CH}_{4} \text { consumption }=\text { maximum consumption rate } \\
& \times\left(0.00332\left[\mathrm{CH}_{4}\right]+0.07326\right) \\
&\left(\mathrm{r}^{2}=0.82 ; \mathrm{R} . \text { E. Kochevar pers. comm. }\right) .
\end{aligned}
$$

The relation between $\mathrm{CO}_{2}$ production $\left(\mu \mathrm{mol} \mathrm{g}^{-1} \mathrm{~h}^{-1}\right.$ ) and methane consumption is: 
$\mathrm{CO}_{2}$ production $=\left[0.31 \times\left(\mathrm{CH}_{4}\right.\right.$ consumption $\left.)\right]+0.89$.

By combining these equations we obtain the following:

$\mathrm{CH}_{4}$ assimilation rate $=0.69$ [maximum consumption rate $\left.\times\left(0.00332\left[\mathrm{CH}_{4}\right]+0.07326\right)\right]-0.89$.

Thus, for a given rate of methane assimilation, the conditions required with respect to the maximum methane consumption rate and methane concentration can be calculated. Isolines given in Fig. $7 \mathrm{~b}$ indicate methane concentrations required for mussels exhibiting a given maximum methane consumption that result in $\mathrm{C} / \mathrm{N}$ balance for total $\mathrm{N}$ assimilation rates from Fig. $7 \mathrm{a}$. $\mathrm{C} / \mathrm{N}$ balance occurs over a relatively narrow range of methane concentrations (Fig. 7b). Since maximum rate of methane consumption varies considerably (1.43 to $9.23 \mu \mathrm{mol} \mathrm{g}^{-1} \mathrm{~h}^{-1}$; Kochevar et al. 1992), let us consider 2 cases: low methanotrophic functioning $\left(2 \mu \mathrm{mol} \mathrm{g}^{-1} \mathrm{~h}^{-1}\right)$ and high methanotrophic functioning $\left(10 \mu \mathrm{mol} \mathrm{g} \mathrm{g}^{-1} \mathrm{~h}^{-1}\right)$. For mussels exhibiting $2 \mu \mathrm{mol} \mathrm{g}{ }^{-1} \mathrm{~h}^{-1}$ maximum consumption rates, $\mathrm{C} / \mathrm{N}$ balance is achieved at $200 \mu \mathrm{M}$ methane for assimilation of $\mathrm{N}$ at a rate of $0.05 \mu \mathrm{mol} \mathrm{g} \mathrm{g}^{-1} \mathrm{~h}^{-1}$, a rate that requires negligible concentrations of ammonium and nitrate in the environment. The maximum ammonium and nitrate concentrations that have so far been observed in water overlying mussels result in $0.08 \mu \mathrm{mol} \mathrm{g}^{-1} \mathrm{~h}^{-1}$ total $\mathrm{N}$ assimilation and require about $240 \mu \mathrm{M}$ methane for $\mathrm{C} / \mathrm{N}$ balance to be achieved. Concentrations of methane above $310 \mu \mathrm{M}$ result in $\mathrm{C}$ assimilation in excess of $\mathrm{C} / \mathrm{N}$ balance for the range of $\mathrm{N}$ assimilation rates given in Fig. $7 \mathrm{a}$. Thus, for mussels exhibiting maximum methane consumption rates of $2 \mu \mathrm{mol} \mathrm{g}^{-1}$ $\mathrm{h}^{-1}$, methane concentrations above $200 \mu \mathrm{M}$ result in methane assimilation in excess of $\mathrm{C}$ requirements for growth. For mussels exhibiting maximum methane consumption rates of $10 \mu \mathrm{mol} \mathrm{g}{ }^{-1} \mathrm{~h}^{-1}$, methane concentrations above $24 \mu \mathrm{M}$ methane result in methane assimilation in excess of $\mathrm{C}$ requirements for growth.

Methane concentrations are variable in areas where seep mytilids are found. MacDonald et al. (1989) reported 0.1 to $66.5 \mu \mathrm{M}$ methane at Bush Hill, and more recent investigations using a sampling system with a small dead volume indicate that methane concentrations can range from 0 to $8000 \mu \mathrm{M}$ (C. R. Fisher pers. comm.). In an earlier study (Lee et al. 1992), we speculated that concentrations of inorganic $\mathrm{N}$ were sufficiently high at the hydrocarbon seeps to be nonlimiting. Although the concentrations are indeed elevated compared with elsewhere in the marine environment, the physiological capacity for seep mytilids to take up and assimilate ammonium and nitrate at environmentally realistic concentrations does not match the capacity for methane uptake and assimilation. Thus, on the time scales involved in our studies, seep mytilids incorporate $\mathrm{C}$ in excess of $\mathrm{N}$ which indicates that mussels are $\mathrm{N}$ limited in situ or that a large proportion of symbiont-derived carbon is ultimately respired by the host.

Acknowledgements. We thank the captains, crewmembers, and pilots of the RV 'Edwin Link', RV 'Seward Johnson', DSRV 'Johnson Sea Link I and II'. NOAA NURP National Undersea Research Center at the University of North Carolina at Wilmington supported Sea Link divetime. We thank C. R. Fisher and K. Scott for assistance at sea. An earlier draft of the manuscript was critically reviewed by $\mathrm{R}$. Trench and M. Brzezinsky. Helpful discussions were contributed by $N$. Ezal and S. Goffredi. This work was supported by ONR grant NOOO14-92-J-11290 and NSF grants DIR-9016074 and OCE9301374 to J.J.C.

\section{LITERATURE CITED}

Anthony C (1982) The biochemistry of methylotrophs. Academic Press, London

Brooks JM, Kennicutt MC, Fisher CR, Macko SA, Cole K, Childress JJ, Bidigare RR, Vetter RD (1987) Deep-sea hydrocarbon seep communities: evidence for energy and nutritional carbon sources. Science 238:1138-1142

Brooks PD, Stark JM, McInteer BB, Preston T (1989) Diffusion method to prepare soil extracts for automated nitrogen-15 analysis. Soil Sci Soc Am J 53:1707-1711

Cary SC, Fisher CR, Felbeck H (1988) Mussel growth supported by methane as sole carbon and energy source. Science 240:78-80

Catmull J, Yellowlees D, Miller DJ (1987) NADP ${ }^{+}$-dependent glutamate dehydrogenase from Acropora formosa: purification and properties. Mar Biol 95:559-563

Childress JJ, Arp AJ, Fisher CR Jr (1984) Metabolic and blood characteristics of the hydrothermal vent tube worm Riftia pachyptila. Mar Biol 83:109-124

Childress JJ, Fisher CR, Brooks JM, Kennicutt MC, Bidgare RR, Anderson AE (1986) A methanotrophic marine molluscan symbiosis: mussels fueled by gas. Science 233 $1306-1308$

D'Elia CF, Cook CB (1988) Methylamine uptake by zooxanthellae-invertebrate symbioses: insights into host ammonium environment and nutrition. Limnol Oceanogr 33: $1153-1165$

Fisher CR, Childress JJ (1992) Organic carbon transfer from methanotrophic symbionts to the host hydrocarbon-seep mussel. Symbiosis 12:221-235

Fisher CR, Childress JJ, Oremland RS, Bidgare RR (1987) The importance of methane and thiosulfate in the metabolism of the bacterial symbionts of two deep-sea mussels. Mar Biol 96:59-71

Johnson KS, Petty RL (1983) Determination of nitrate and nitrite in seawater by flow injection analysis. Limnol Oceanogr 28:1260-1266

Kennicutt MC, Burke RA, MacDonald IR, Brooks JM, Denoux GJ, Macko SA (1992) Stable isotope partitioning in seep and vent organisms: chemical and ecological significance. Chem Geol 101:293-310

Kochevar RE, Childress JJ, Fisher CR, Minnich E (1992) The methane mussel: roles of symbiont and host in the metabolic utilization of methane. Mar Biol 112:389-401

Lee RW, Childress JJ (1994) Assimilation of inorganic nitrogen by chemoautotrophic and methanotrophic symbioses. Appl environ Microbiol 60:1852-1858 
Lee RW. Thuesen EV, Childress JJ (1992) Ammonium and free amino acids as nitrogen sources for the chemoautotrophic clam symbiosis Solemya reidi Bernard (Bivalvia: Protobranchia). J exp mar Biol Ecol 158:75-91

Lee RW, Thuesen EV, Childress JJ, Fisher CR (1992) Ammonium and free amino acid uptake by a deep-sea mussel containing methanotrophic bacterial symbionts. Mar Biol 1.13:99-106

MacDonald IR, Boland GS, Baker JS, Brooks JM, Kennicutt II MC, Bidigare RR (1989) Gulf of Mexico hydrocarbon seep communities II. Spatial distribution of seep organisms and hydrocarbons at Bush Hill. Mar Biol 101:235-247

MacDonald IR, Callender WR, Burke RA, MCDonald SJ, Carney RS (1990a) Fine-scale distribution of methanotrophic mussels at a Louisiana cold-seep. Prog Oceanogr 24:15-24

MacDonald IR, Reilly II JF, Guinasso NL Jr, Brooks JM, Carney RC, Bryant WA, Bright TJ (1990b) Chemosynthetic mussels at a brine-filled pockmark in the northern Gulf of Mexico. Science 248:1096-1099

Male KB, Storey KB (1983) Kinetic characterization of NADPspecific glutamate dehydrogenase from the sea anemone Anthopleura xanthogrammica: control of amino acid biosynthesis during osmotic stress. Comp Biochem Physiol $76 \mathrm{~B}: 823-829$

Muscatine L, D'Elia CF (1978) The uptake, retention and release of ammonium by reef corals. Limnol Oceanogr 23 : $725-734$

Muscatine L, Masuda H, Burnap R (1979) Ammonium uptake by symbiotic and aposymbiotic reef corals. Bull mar Sci 29 : $572-575$

Owens NJP (1988) Rapid and total automation of shipboard ${ }^{15} \mathrm{~N}$ analysis examples from the North Sea. J exp mar Biol Ecol 122:163-171

Owens NJP, Rees AP (1989) Determination of Nitrogen-15 at sub-microgram levels of nitrogen using automated continuous-flow isotope ratio mass spectrometry. Analyst 114 $1655-1657$

This article was submitted to the editor
Page HM, Fisher CR, Childress JJ (1990) Role of filter-feeding in the nutritional biology of a deep-sea mussel with methanotrophic symbionts. Mar Biol 104:251-257

Preston T, McMillan DC (1988) Rapid sample throughput for biomedical stable isotope tracer studies. Biomed environ Mass Spect 16:229-235

Rahav O, Dubinsky Z, Achituv Y, Falkowski PG (1989) Ammonium metabolism in the zooxanthellate coral, Stylophora pistillata. Proc R Soc Lond (Ser B) 236:325-337

Rees TAV (1987) The green hydra symbiosis and ammonium 1. The role of the host in ammonium assimilation and its possible regulatory significance. Proc R Soc Lond (Ser B) 229:299-314

Summons RE, Boag TS, Osmond CB (1986) The effect of ammonium on photosynthesis and the pathway of ammonium assimilation in Gymnodinium microadriaticum in vitro and in symbiosis with Tridacnid clams and corals. Proc R Soc Lond (Ser B) 227:147-159

Summons RE, Osmond CB (1981) Nitrogen assimilation in the symbiotic marine alga Gymnodinium microadriaticum: direct analysis of ${ }^{15} \mathrm{~N}$ incorporation by GC-MS methods. Phytochemistry 20:1981

Szmant AM, Ferrer LM, FitzGerald LM (1990) Nitrogen excretion and $\mathrm{O}: \mathrm{N}$ ratios in reef corals: evidence for conservation of nitrogen. Mar Biol 104:119-127

Wilkerson FP, Kremer P (1992) DIN, DON and $\mathrm{PO}_{4}$ flux by a medusa with algal symbionts. Mar Ecol Prog Ser 90: $237-250$

Wilkerson FP, Muscatine L (1984) Uptake and assimilation of dissolved inorganic nitrogen by a symbiotic sea anemone. Proc R Soc Lond (Ser B) 221:71-86

Wilkerson FP, Trench RK (1986) Uptake of dissolved inorganic nitrogen by the symbiotic clam Tridacna gigas and the coral Acropora sp. Mar Biol 93:237-246

Willason SW, Johnson KS (1986) A rapid, highly sensitive technique for the determination of ammonia in seawater. Mar Biol 91:285-290

Manuscript first received: July 15, 1994

Revised version accepted: February 2, 1995 